\title{
A Clostridium difficile onkológiai vonatkozásai
}

\author{
Telekes András dr. \\ Bajcsy-Zsilinszky Kórház, Onkológiai Osztály, Budapest
}

\begin{abstract}
A Clostridium difficile az egyik leggyakoribb fertőzés a daganatos betegek között. Diagnózisát nehezíti, hogy a fertőzés tünetei és az onkológiai kezelések mellékhatásai hasonlóak lehetnek. Maga a kemoterápia is elősegítheti a Clostridium difficile-infekció kialakulását. Bár számos kockázati faktor ismert, ezek hiányában is kialakulhat a fertőzés. A fatális Clostridium difficile-infekció kockázati faktora a neutropenia, ami egyben a kemoterápia mellékhatása is. Ezért, ha daganatos betegek esetén a potenciális infekció tünetei megjelennek (például diarrhoea naponta több mint háromszor, $38,5^{\circ} \mathrm{C}$-ot meghaladó láz, colitis, szérumkreatinin-szint gyors emelkedése) a Clostridium difficile-fertőzést ki kell zárni. Amennyiben a fertőzés igazolódik, azt a leghatékonyabb módon kezelni kell. Orv. Hetil., 2016, $157(28), 1110-1116$.
\end{abstract}

Kulcsszavak: Clostridium difficile, onkológia, fidaxomicin

\section{Oncologic aspects of Clostridium difficile}

\begin{abstract}
Clostridium difficile infection is one of the most frequent among cancer patients. Its diagnosis is complicated by the fact that the symptoms of the infection and the side effects of the anticancer treatments could be similar. Chemotherapy itself might facilitate Clostridium difficile infection. Several risk factors are known but Clostridium difficile infection can develop in the absence of these. Neutreopenia is a risk factor for fatal Clostridium difficile infection and also the side effect of chemotherapy. Therefore, if symptoms of the potential infection develop (eg. diarrhoea more than three times a day, fever above $38.5^{\circ} \mathrm{C}$, colitis, rapid increase of serum creatinin) Clostridium difficile infection should be excluded. If the infection is confirmed it should be managed in the most efficient way.
\end{abstract}

Keywords: Clostridium difficile, oncology, fidaxomicin

Telekes, A. [Oncologic aspects of Clostridium difficile]. Orv. Hetil., 2016, 157(28), 1110-1116.

(Beérkezett: 2016. március 5.; elfogadva: 2016. április 17.)

\section{Rövidítések}

$\mathrm{CD}=$ Clostridium difficile $; \mathrm{CDAD}=$ Clostridium difficile-aszszociált diarrhoea; EIA = enzimimmunoassay; $\mathrm{PCR}=$ polimeráz láncreakció; $\mathrm{Tcd} \mathrm{A}=$ Clostridium difficile toxin $\mathrm{A} ; \mathrm{TcdB}=$ Clostridium difficile toxin $\mathrm{B}$

\section{A Clostridium difficile}

A Clostridium difficile (CD) az ember normális bélflórájának része. Azonos családba tartozik, mint a patogén Clostridium tetani (ami a tetanust okozza) és a Clostridium botullinum (ami a botulizmust okozza). Mindenütt előfordul (levegő, víz, talaj, széklet, bármilyen felület), leggyakrabban WC-ülőkén, pelenkákon, padlón, telefonokon, körmökön, ékszereken, sztetoszkópon, háziállatokon, zöldségeken mutatták ki. A CD Gram-pozitív anaerob baktérium. A bélflórában lévő baktériumok egymás növekedését kordában tartják. Az aktív, infektív baktérium nem képes ellenállni a környezeti hatásoknak hosszú időn keresztül. Az inaktív forma, az úgynevezett spóra, azonban szabad levegőn, szennyeződésekben akár két évig is életképes. A spóra maga nem fertőző, de a bélbe jutva, belélegezve visszanyerheti infektív formáját. Antibiotikum-kezelést követően, amikor a bélflóra egyensúlya felborul, a CD-spórák a bélben aktív formává alakulnak és képesek gyorsan elszaporodni. Az aktív bak- 
térium toxinokat termel, ami a vastagbél gyulladásos betegségéhez vezet (CD-colitis) [1]. Orvosi szempontból két toxin alapvető (Clostridium difficile toxin A [TcdA] és Clostridium difficile toxin B [TcdB]), ezek potens enterotoxinok, amelyek proinflammatorikus szignálokat indukálnak a gazdaszervezetben [2]. Mindkettő a bélfalat irritálja, a bélmucosa sérülését, majd gyulladását és ezáltal bélbetegség tüneteit okozzák [3]. A toxinok következtében kialakuló mucosasérülés helyére fehérvérsejtek vándorolnak. A lokálisan kialakuló gyulladásos, genynyes foltok a bélfal speciális, diagnosztikus értékü elváltozását okozzák (pseudomembranosus colitis). Kezelés nélkül akár bélfekélyek is kialakulhatnak. A korai tünetek az ételmérgezés tüneteivel lényegében megegyeznek (hasmenés, bélgörcsök). Enyhe esetben a tünetek mérsékelt lázzal, enyhe hasmenéssel, gyomorgörcsökkel, enyhe nyomásérzékenységgel járnak, néhány napig tartanak. Súlyosabb esetekben ezeket gyengeség, magas láz, hányás, hányinger, étvágytalanság, fogyás, dehidráció (a naponta akár tízszer vagy többször kialakuló hasmenés miatt) követheti. Ha a dehidráció gyors, akár veseelégtelenség is kialakulhat. Előrehaladott állapotban a széklet többnyire véres-nyákos. Kezelés nélkül a kórlefolyás toxikus megacolonhoz, bélperforációhoz, halálhoz vezethet. A CD a leggyakoribb nosocomialis, azaz egészségügyi intézetben szerzett fertőzés [4]. Fontos, hogy a szokásos takarítószerek nem pusztítják el a spórákat, így az infektív/aktív CD kiirtása után a beteg a környezetéből újrafertőződhet. A lymphopenia a rekurrens CD-fertőzés markere lehet [5].

Ki kell hangsúlyozni, hogy nem mindenkinél alakul ki vastagbélgyulladás, aki CD-fertőzött. Ezek az úgynevezett hordozók, akik azonban képesek továbbadni a baktériumot. Feltételezik, hogy a hordozók az aktív baktérium toxinjai ellen antitesteket képeztek, ezért nem jelenik meg esetükben a gyulladás.

A CD az antibiotikum-terápia mellett kialakuló hasmenés oka 20-30\%-ban, az antibiotikum-terápia mellett kialakuló vastagbélgyulladás oka 50-70\%-ban és az antibiotikum-terápia mellett kialakuló pseudomeranosus colitis oka több mint 90\%-ban [6]. Nem teljesen tisztázott, hogy az antibiotikum-kezelés miért kockázati tényező a CD-infekció vonatkozásában. Az alapvető elképzelés az, hogy a normális bélflóra gátolja a spórák aktív baktériummá való átalakulását, így az antibiotikum okozta intestinalis mikroflóra-változás a CD-fertőzés prediszponáló faktora. Adatok vannak arra vonatkozóan is, hogy egyes antibiotikumok megváltoztathatják a CD béladhézióját, illetve fokozhatják a CD-toxin termelését [7].

Clostridium difficile-asszociált diarrhoea (CDAD) gyanúja akkor merül fel, ha egy betegnek egy nap háromszor vagy annál többször van híg, vízszerü hasmenése, amelynek nincs kimutatható oka. Egy vizsgálat során azt találták, hogy a CDAD incidenciája 1,7/1000 betegnap volt az onkológiai betegek esetén, és 2,4/1000 betegnap az őssejttranszplantáltak esetén, ami 6-9-szer magasabb volt, mint a többi hospitalizált beteg esetén észlelt érték [8]. Leggyakrabban clindamycin-, cefalosporin-, illetve ampicillinterápiához társulva írták le a CD okozta hasmenést, de számos más antibiotikummal kapcsolatban is észlelték [9]. A CD-infekció tünetei kialakulhatnak az antibiotikum-kezelés alatt, annak befejezését követően néhány nappal, de a latenciaidő akár 8 hét is lehet. A kórlefolyás lehet enyhe, közepes vagy súlyos (1. táblázat).

\section{A diagnózis}

Tekintettel arra, hogy a fertőzés tünetei hasonlítanak más bélbetegség tüneteire, a diagnózis a székletminta laboratóriumi vizsgálatán alapul. A laboratóriumi diagnózis leggyakoribb módja a CD-toxin kimutatása a székletből. Ez történhet enzimimmunoassay (EIA) vagy polymerase chain reaction (PCR) alkalmazásával. Egy friss közleményben a két módszert összevetették. Három csoportot képeztek (EIA-/PCR+, EIA+/PCR+, EIA-/PCR-) és a klinikai kórlefolyást tanulmányozták. Az EIA-/PCR + csoportban nem észleltek komplikációt, míg az EIA+/PCR+ csoportban 10 komplikációt észleltek $(0 \%$ vs. $7,6 \%, \mathrm{p}<0,001)$. Ami ennél is fontosabb, az EIA-/PCR + csoportban 1 beteg esetén észleltek rekurrens fertőzést, ami hozzájárult a beteg 30 napon belüli

1. táblázat $\mid$ A CD-infekció jellemző tünetei enyhe, középsúlyos és súlyos esetekben

\begin{tabular}{|c|c|c|}
\hline Tünetek enyhe esetben & Tünetek középsúlyos esetben & Tünetek súlyos esetben \\
\hline $\begin{array}{l}\text { - Fizikális vizsgálat negatív } \\
\text { - Enyhe-közepes mértékú hasmenés }(\geq 3 / \text { die }) \\
\text { - A széklet nem véres }\end{array}$ & $\begin{array}{l}\text { - Hasi fájdalom, vagy diszkomfortérzés } \\
\text { - Nagy mennyiségű, vízszerü hasmenés } \\
\text { - Okkult vérzés a székletben } \\
\text { - Láz előfordulhat } \\
\text { - Leukocytosis (kemoterápia, } \\
\text { immunszupprimált állapot elfedheti) }\end{array}$ & $\begin{array}{l}\text { - Komoly hasi fájdalom, feszülésérzés } \\
\text { (dystensio) } \\
\text { - Súlyos tünetek megjelenése: } \\
\text { - Colitis } \\
\text { - Szepszis } \\
\text { - Peritonitis } \\
\text { - Volumendepléció } \\
\text { - Vérnyomásesés } \\
\text { - Ionháztartási zavar } \\
\text { - Veseelégtelenség } \\
\text { - Paralyticus ileus } \\
\text { - Toxikus megacolon }\end{array}$ \\
\hline
\end{tabular}


halálához, míg az EIA+/PCR+ csoportban 11 CD-infekció miatt bekövetkezett haláleset volt $(0,6 \%$ vs. $8,4 \%$, $\mathrm{p}=0,001)$. A szerzők szerint a PCR kizárólagos használata túldiagnózishoz és túlkezeléshez vezethet, mivel az EIA-/PCR + csoport kimenetele nem különbözött attól a csoporttól, akiknél mindkét teszt eredménye negatív volt (EIA-/PCR-) [10]. Ha a széklet véres, a kolonoszkópia sokszor szükséges differenciáldiagnosztikai szempontból (egyéb gyulladásos bélbetegség, daganat), illetve a pseudomembranosus elváltozás igazolására. CT alkalmazása indokolt lehet a megacolon vagy bélperforáció kimutatására. Fontos, hogy a tünetek kialakulása után diagnózishoz kell jutni, mert egy másik antibiotikum ex juvantibus alkalmazása a CD esetleges további túlszaporodásához és akár a tünetek rosszabbodásához vezethet.

\section{Kockázati faktorok}

Mivel a tünetek nem specifikusak, a CD-fertőzés kockázati faktorainak ismerete elősegítheti a gyorsabb diagnózist, mert gondolnak rá, még a betegség korai szakaszában. A legfontosabb kockázati tényezők:

- Aktuális vagy közelmúltban történő antibiotikum-terápia [11]. (Ha valaki széles spektrumú antibiotikumot kapott vagy hosszabb ideig volt antibiotikum-kezelésen, a kockázat fokozott.)

- A 65 éves vagy annál idősebb életkor [12]. (Ebben a korosztályban a CD-fertőzés kockázata 10-szer nagyobb, mint a fiatal korosztályban.)

- Aktuális vagy nemrég történt hospitalizáció [13]. (Minél hosszabb ideig volt valaki kórházban, annál nagyobb a kockázat.)

- Ápolási vagy öregotthonban történő tartós életvitel [14].

- Valamilyen komolyabb társbetegség, különösen, ha ez az immunrendszer múködését negatívan befolyásolja (például kemoterápiában részesülő daganatos beteg) [15].

- Közelmúltban történt hasi mútét vagy gastrointestinalis beavatkozás [16].

- Egyéb bélbetegség [17]. (Például gyulladásos bélbetegség, vastagbéldaganat.)

- Korábbi CD-fertőzés [18].

- Protonpumpa-inhibitor terápia [19]. (Feltételezik, hogy a gyomorsav fertőtlenítő hatásának elmaradása kockázati tényező a relapsus vonatkozásában.)

- Szondatáplálás [20].

\section{A terápia}

Habár az antibiotikum-terápia maga is kockázati tényező a CD-fertőzés vonatkozásában, mégis a kezelés elsődlegesen antibiotikum-terápia. Első vonalban régebben a metronidazol (például $500 \mathrm{mg}$ per os, naponta 3-szor, 10 napig), ha ez nem volt hatékony, vancomycin (például $125 \mathrm{mg}$ per os, naponta négyszer, 10-14 napig) volt a standard kezelés. Mivel előfordul, hogy a CD nem reagál ezekre a gyógyszerekre, és a fertőzés hosszú időn át perzisztál, újabb kezelési lehetőségeket dolgoztak ki, részint új gyógyszerek, részint az úgynevezett fekális bakterioterápia (széklettranszplantáció) formájában. A CD kezelésére ajánlott egyik legújabb antibiotikum a fidaxomicin. Fidaxomicin az első orális antibiotikum, amit kifejezetten a CD ellen fejlesztettek ki, ezáltal a bél normálflórájára csak minimális hatással van [21]. A minimális gátlókoncentráció (MIC) a CD ellen alacsonyabb, mint a metronidazol vagy vancomycin esetén. A fidaxomicin az RNS-polimeráz hatékony gátlója, ami által direkt akadályozza a bakteriális fehérjék és indirekt módon a baktérium DNS-szintézisét [22]. Daganatos betegeken végzett direkt összehasonlításban a fidaxomicin hatékonyabbnak bizonyult a vancomycinnél [23]. A fidaxomicin $(200 \mathrm{mg}$ per os, naponta 2 -szer, 10 napig) jelenleg elsőként választandó rekurrens vagy a visszaesés vonatkozásában nagy kockázatú CD-fertőzés esetén [24], különösen azoknál, akik egyéb antibiotikumot kapnak [25], vesemúködési zavarban [26] vagy daganatos betegségben [27] szenvednek, illetve idősek [28]. Kiemelendő, hogy az első CD-fertőzésből sikeresen felépülők egyharmada visszaesik [29]. Éppen ezért első kezelésként nem a metronidazolt, hanem a vancomycint vagy a fidaxomicint javasolják, ha: 1) fvs. >15 $\left.10^{9} / 1 ; 2\right)$ gyorsan emelkedik a szérumkreatinin (például $>50 \%$ a kiindulási értékhez képest); 3) a láz $>38,5{ }^{\circ} \mathrm{C}$; 4 ) súlyos colitis kimutatható.

A széklettranszplantáció célja a normális baktériumflóra visszaállítása a CD-fertőzés természetes szanálására [30].

Daganatos betegek esetén a Grade 2-3 diarrhoea esetén addig, amíg a székletminta CD-toxin-tesztje megérkezik, antiperisztaltikus kezelést kell kezdeni. (Loperamid telítődózis $4 \mathrm{mg}$, majd $2 \mathrm{mg}$ minden hasmenéses széklet esetén, maximum 8 tablettáig, ha ez nem bizonyul kellő hatékonyságúnak, octreotiddal kell a kezelést kiegészíteni [31].)

\section{Prevenció}

A kórházakban általában szigorú infekciókontroll-előírások léteznek a CD-fertőzés kitörésének megelőzésére és megállítására. Ezek közül a legalapvetőbbek:

- A kézmosás: Minden beteg bármilyen ellátása előtt és után alapos, meleg vízzel történő szappanos kézmosás és alkoholos kézfertőtlenítés szükséges az egészségügyi személyzet részéről. Minden beteglátogatónak ugyanez javasolt, legalább a látogatást követően. A betegek számára is gyakori kézmosás szükséges.

- A kontaktus: A CD-fertőzött külön kórteremben történő elhelyezése javasolt, esetleg más CD-fertőzöttel lehet egy kórteremben. Az ismerten CD-fertőzött beteget csak gumikesztyúben, maszkban és köpenyben lehet ellátni, látogatni.

- A tisztaság: A CD-fertőzött beteg kórtermében valamennyi felület (padló, éjjeliszekrények stb.) klóros 
fertőtlenítőszerrel való rendszeres lemosása javasolt, mivel ezt a spórák nem élik túl. Külön gondot kell fordítani a beteg által használt WC/fürdőszoba tisztítására.

- Antibiotikum-használat: Manapság az antibiotikumok adására akkor is sor kerül, amikor az elkerülhető vagy szükségtelen. Utóbbira példa a vírusfertőzés (meghülés), amely esetben az antibiotikumok hatástalanok, mégis gyakran felírják. Az antibiotikum-terápia, ha szükséges, célzott kezeléssel végzendő és a lehető legrövidebb ideig adandó.

\section{A CD onkológiai vonatkozásai}

A Salmonella, Shigella, Yersinia, illetve Campylobacter okozta enteritis ritka a daganatos betegek körében [32], ezzel szemben a CD-fertőzés az egyik leggyakoribb [33]. A CD szerepe daganatos betegek esetén még nem kellőképpen tisztázott, ugyanakkor számos potenciális összefüggés vethető fel. A daganatos betegek immunszuppresszív kezelésben részesülnek és ilyenkor fokozódhat a fertőzések száma. A kemoterápia mucositist okozhat, csökkentheti a fehérvérsejtszámot. A neutropenia miatt a betegek sokszor antibiotikum-kezelést kapnak [34]. A daganatkemoterápia ezért prediszponáló faktor lehet a CD-fertőzések vonatkozásában [35].

$\mathrm{Az}$ emberi bél baktériumflórája komplex ecologiai rendszer. A bélben hozzávetőleg 100 trillió baktérium található, körülbelül 40000 különféle baktérium formájában. Az ezekben található gének összesített száma minimum az emberi genom százszorosa. A baktériumok a széklettartalom felét teszik ki. A CDAD előfordulása daganatos betegekben számottevő, szolid tumorosok esetén 9-13\%, őssejttranszplantáltak esetén akár 33\% [36]. A CDAD mortalitása 0,5-2,0\% [37]. A kemoterápia önmagában is megváltoztathatja a baktérium-mikroflórát a bélben [38]. Kemoterápiával összefüggésben többször közöltek már CDAD-t, többek között: 5-fluorouracil [39], paclitaxel-carboplatin [40], cisplatinalapú kezelés [41], S1, illetve irinothecan [42], VPB (vincristin, cisplatin, bleomycin), 5-FU, methotrexat, cyclophosphamid, doxorubicin, cytarabin, CHOP (cyclophosphamid, doxorubicin, vincristin, prednisolon $)+$ bleomycin + methotrexat, vinblastin + chlorambucil + procarbazin [43]; vepesid, AraC [44], vinorelbin [45], docetaxel [46].

A kemoterápiás szerek eltéró módon vezethetnek CDinfekcióhoz [47]. A platina, 5-FU és methotrexat mucositist okoz, ami a következményes necrosisokkal jár, így megfelelő anaerob körülmények alakulnak ki a spórák aktiválódásához és a baktériumok szaporodásához. A gyulladás következtében proteingazdag intraluminalis folyadék akkumulálódik, amely miatt csökken a CD-toxinok degradációja. A DNS-topoizomeráz-gátlók (például irinothecan) csökkentik a mucosalis epithelsejtek repair kapacitását, ezáltal elősegítik a CD kolonizációját, illetve fokozzák a CD-relapsus frekvenciáját.
Egy vizsgálatban 400 olyan daganatos beteg székletmintáját vizsgálták, akik kemoterápiás kezelésben részesültek [48]. A minták 20,5\%-a (82 minta) pozitív volt. A hasmenéses betegek esetén a pozitív minták száma $35 \%$ volt, a nem diarrhoeások esetén csak 19,7\% ( $\mathrm{p}=$ 0,09). Érdekes módon azt találták, hogy az 50 évnél fiatalabb és legalább 10 napja hospitalizált betegek esetén a pozitív minták aránya 35\% volt, míg az 50 évnél idősebb és kevesebb mint 10 napja hospitalizált betegek esetén ugyanez csak $12,7 \%$ volt $(\mathrm{p}=0,0009)$. A pozitív minták nem mutattak összefüggést az alkalmazott kemoterápiás protokollal, antibiotikum alkalmazásával, illetve immunszuppresszív mediátorok (prosztaglandin-E2, transforming growth factor beta, interlukin-10) szintjével. Egy másik tanulmányban tüdőtumoros betegek esetén vizsgálták a CD incidenciáját [49]. A 188 beteg közül 44 $(23,4 \%)$ volt CD-pozitív. A CD-pozitívak esetén az albuminérték $(2,8 \pm 0,6 \mathrm{~g} / \mathrm{dl})$ alacsonyabb volt, mint a CDnegatív betegek esetén észlelt $(3,2 \pm 0,6 \mathrm{~g} / \mathrm{dl})$, ami szignifikánsnak bizonyult $(\mathrm{p}<0,05)$. Mivel a CD-pozitív betegek fizikális státusa (PS) is szignifikánsan rosszabb volt annak ellenére, hogy a daganatos betegség stádiumeloszlása a két csoport között nem különbözött, a szerzők arra a következtetésre jutottak, hogy alacsony albuminszint és magas PS-score esetén a kezelőorvosnak gondolnia kell az esetleges CD-fertőzésre.

Hematológiai betegek 875 mieloszuppresszív kemoterápiás ciklusát tanulmányozták retrospektív módon [50]. CDAD az összes ciklus 7\%-ában fordult elő. Bár egy beteget sem vesztettek el CD-infekció miatt, a szerzők mégis arra a következtetésre jutottak, hogy minden hospitalizált neutropeniás beteg esetén, akinél hasmenés alakul ki, a CD-infekciót ki kell zárni. Egy metaanalízis során 48 vizsgálatban részt vevő 12025 , őssejt-transzplantáción átesett beteg adatait elemezték és a CD-fertőzés előfordulását 7,9\%-nak (95\% CI 6,5\%-9,5\%) becsülték [51]. Érdekes módon az 5120, allogén transzplantációban részesülő beteg között szignifikánsan több volt a CD-infekció (9,3\% [95\% CI 7,0\%-11,9\%]), mint a 4665, autológ csontvelővel transzplantált beteg esetén $(5,2 \%$ [95\% CI 3,8\%-6,9\%], p = 0,02). Allogén őssejt-transzplantáció alatt a betegek kialakuló CD-fertőzése azonban ritkán életveszélyes [52]. A betegség kimenetele nem különbözik a hematológiai betegségben szenvedők és nem malignus betegségben szenvedők között [53]. Egy másik tanulmányban azonos kórtermekben elhelyezett, azonos fürdőszobákat és mellékhelyiségeket használó, azonos személyzet által ellátott 135 malignus hematológiai és 113 nem malignus betegségben szenvedő beteg székletmintáit vizsgálták CD-fertőzés vonatkozásában, akiket egy 6 hónapos időperiódus alatt kezeltek [54]. A malignus betegségben szenvedők között 49 (36,2\%), az egyéb belgyógyászati betegség miatt kezeltek között $13(11,5 \%)$ minta volt pozitív. Az antibiotikum adása nem befolyásolta a csoportok közti különbséget, miként a neutropenia, szteroid adása, illetve a kemoterápia sem. Például a malignus betegségben 
szenvedők közül, akiknél a CD-fertőzés nem igazolódott, 78\% részesült antibiotikum-kezelésben, a pozitív mintát produkáló betegek esetén ez $80 \%$ volt. A 49 pozitív mintát adó, malignus hematológiai betegségben szenvedő közül $37(75,5 \%)$ akut leukaemiában szenvedett. A szerzők szerint az akut leukaemia vagy annak kezelése fontos kockázati faktor a CD-fertőzés vonatkozásában.

\section{Megbeszélés}

A vastagbéldaganatos betegek esetén végzett hemicolectomia gyakran eredményez tartós laza, esetleg híg székletet. Mi több, hasmenést maga a kemoterápia is okozhat, ezért, ha nem gondolunk rá, a CD-fertőzés a daganatos, különösen béldaganatos betegek esetén nem diagnosztizált.

A CD egészséges felnőttekben csak 2-3\%-ban kolonizál, azonban hospitalizált betegek esetén ez elérheti a 20-30\%-ot [55]. Ez a tény önmagában is igazolja, hogy a betegségek és/vagy kezelések prediszponáló tényezők. Egy 4000 betegen történő vizsgálat azt igazolta, hogy az infekció jeleivel kórházba került betegek elsősorban a CD NAPl/027 törzsével fertőződtek, míg az aszimptomatikus betegek döntően más törzsekkel [56]. Az infekció tüneteit mutató betegek hozzávetőleg egynegyede intenzív ellátásra szorul, de azt is fontos tudni, hogy az idősotthonokban élők 5-7\%-a tünetmentes hordozó. Egy tanulmány adatai szerint a CD-infekció okozta halálozás 92\%-a a 65 évnél idősebbek között fordul elő, így ebben a korosztályban a CD-infekció a 18. leggyakoribb halálok [57].

Az antibiotikumok adekvát használata fontos tényező a CD-infekció vonatkozásában. Egy vizsgálatban összehasonlították a CD-infekció kockázatát $(\mathrm{HR}$ = hazard ratio) azon betegek esetén, akik korábban csak egy antibiotikumot kaptak, azokkal, akik 2, 3-4 vagy 5 antibiotikumot kaptak, az eredmény a fenti sorrend szerint (az egy antibiotikumot kapókhoz képest) 2,5, 3,3, illetve 9,6 volt [58]. Fontos, hogy a CD-infekció kockázata antibiotikum-terápiát követően még három hónapig fokozott marad [59]. A hatékony antibiotikum-kezelés ellenére a visszaesés gyakori, becslések szerint $25 \%$ az elsó fertőzést követő 3 hónapban, illetve $45 \%$ az első relapsust követően [60]. A relapsusok döntő többsége az elsődlegesen adott metronidazol- vagy vamcomycinkezelés befejezését követő 2-3 héten belül történik [61]. Az immunszuppresszív kezelés alatt álló daganatos betegek kockázata magas a relapsus vonatkozásában, mi több, a CD-fertőzés az onkológiai kezelés halasztását, felfüggesztését vagy befejezését eredményezheti. A fidaxomicin a vancomycinnel azonos hatékonyságúnak (88\%, illetve $86 \%$ ) bizonyult az első CD-infekció kezelésében, de sokkal kevesebb volt a relapsus fidaxomicint követően (14\% vs. 26\%) [62]. Egy onkológiai centrumban 22 daganatos beteget ( 9 lymphoma, 7 leukaemia, 6 szolid tumor) vizsgáltak, akiknél fidaxomicinkezelésre tartós terá- piás választ észleltek 82\%-ban a CD-infekció standard kezelésének kudarca után [63]. A fentiek alapján a fidaxomicin a daganatos betegek számára is ajánlott kezelés. Nagy esetszámú vizsgálatok nem mindig mutattak összefüggést az ismert vagy feltételezett kockázati faktorokkal, így ezek hiányában is, a tünetek esetén, a CD-fertőzésre gondolni kell. Mivel daganatos betegekben a neutropenia a fatális CD-infekció kockázati faktora [64], neutropeniás beteg esetén akár kap aktív onkológiai kezelést, akár nem, a CD-infekciót ki kell zárni, pozitív esetben aktívan kezelni kell (például fidaxomicin). Fontos, hogy nem találtak összefüggést a CD-infekció és egy adott kemoterápiás szer/protokoll között [65]. Ugyanakkor, úgy tûnik, hogy az IgA-myeloma protektív hatású a CD-infekció szempontjából [66].

Anyagi támogatás: A közlemény megírása anyagi támogatásban nem részesült.

A cikk végleges változatát a szerző elolvasta és jóváhagyta.

Érdekeltségek: A szerzőnek nincsenek érdekeltségei.

\section{Irodalom}

[1] Kelly, C. P., Pothoulakis, C., LaMont, J. T.: Clostridium difficile colitis. N. Engl. J. Med., 1994, 330(4), 257-262.

[2] Cowardin, C. A., Petri, W. A. Jr:: Host recognition of Clostridi$u m$ difficile and the innate immune response. Anaerobe, 2014, 30, 205-209.

[3] Voth, D. E., Ballard, J. D.: Clostridium difficile toxins: mechanism of action and role in disease. Clin. Microbiol. Rev., 2005, $18(2), 247-263$.

[4] Kelly, C P., LaMont, J. T.: Clostridium difficile - more difficult than ever. N. Engl. J. Med., 2008, 359(18), 1932-1940.

[5] Lavergne, V., Beauséjour, ., Pichette, G., et al.: Lymphopenia as a novel marker of Clostridium difficile infection recurrence. J. Infect., 2013, 66(2), 129-135.

[6] Cohen, S. H., Gerding, D. N., Johnson, S., et al.: Clinical practice guidelines for Clostridium difficile infection in adults: 2010 update by the Society for Healthcare Epidemiology of America (SHEA) and the Infectious Diseases Society of America (IDSA). Infect. Control Hosp. Epidemiol., 2010, 31(5), 431-455.

[7] Baarc, M.C., Depitre, C., Corthier, G., et al.: Effects of antibiotics and other drugs on toxin production in Clostridium difficile in vitro and in vivo. Antimicrob Agents Chemother 1992, 36(6), $1332-1335$.

[8] Chopra, T., Chandrasekar, P., Salimnia, H., et al.: Recent epidemiology of Clostridium difficile infection during hematopoietic stem cell transplantation. Clin. Transplant., 2011, 25(1), E82E87.

[9] Starr, J. M., Impallomeni, M.: Risk of diarrhoea, Clostridium difficile and cefotaxime in the elderly. Biomed Pharmacother 1997, $51(2), 63-67$.

[10] Polage, C. R., Gyorke, C. E., Kennedy, M. A., et al.: Overdiagnosis of Clostridium difficile infection in the molecular test era. JAMA Intern. Med., 2015, 175(11), 1792-1801.

[11] Kaier, K., Frank, U.: Relationship between antibiotic consumption and Clostridium difficile-associated diarrhea: an epidemiological note. Antimicrob. Agents Chemother., 2009, 53(10), $4574-4575$. 
[12] Biagi, E., Nylund, L., Candela, M., et al.: Through ageing, and beyond: gut microbiota and inflammatory status in seniors and centenarians. PLoS ONE, 2010, 5(5), e10667.

[13] McDonald, L. C., Owings, M., Jernigan, D. B.: Clostridium difficile infection in patients discharged from US short-stay hospitals, 1996-2003. Emerg. Infect. Dis., 2006, 12(3), 409-415.

[14] Al-Tureibi, F. I., Hassoun, A., Wolf-Klein, G., et al.: Albumin, length of stay, and proton pump inhibitors: key factors in Clostridium difficile-associated disease in nursing home patients. J. Am. Med. Dir. Assoc., 2005, 6(2), 105-108.

[15] Fainstein, V., Bodey, G. P, Fekety, R.: Relapsing pseudomembranous colitis associated with cancer chemotherapy. J. Infect. Dis., $1981,143(6), 865$

[16] Yeom, C. H., Cho, M. M., Baek, S. K., et al.: Risk factors for the development of Clostridium difficile-associated colitis after colorectal cancer surgery. J. Korean Soc. Coloproctol., 2010, 26(5), 329-333

[17] Gérard, M., Defresne, N., Van der Auwera, P., et al.: Polymicrobial septicemia with Clostridium difficile in acute diverticulitis. Eur. J. Microbiol. Infect. Dis., 1989, 8(4), 300-302.

[18] Hebert, C., Du, H., Peterson, L. R., et al: Electronic health record-based detection of risk factors for Clostridium difficile in fection relapse. Infect. Control Hosp. Epidemiol., 2013, 34(4), 407-414.

[19] Kim, J. W., Lee, K. L., Jeong, J. B., et al.: Proton pump inhibitors as a risk factor for recurrence of Clostridium-difficile-associated diarrhea. World J. Gastroenterol., 2010, 16(28), 3573-3577.

[20] O'Keefe, S. J.: Tube feeding, the microbiota, and Clostridium difficile infection. World J. Gastroenterol., 2010, 16(2), 139-142.

[21] Louie, T. J., Cannon, K., Byrne, B., et al.: Fidaxomicin preserves the intestinal microbiome during and after treatment of Clostridium difficile infection (CDI) and reduces both toxin re-expression and recurrence of CDI. Clin. Infect. Dis., 2012, 55(Suppl. 2), S132-S142.

[22] Sergio, S., Pirali, G., White, R., et al.: Lipiarmycin, a new antibiotic from Actinoplanes III. Mechanism of action. J. Antibiot. (Tokyo), 1975, 28(7), 543-549.

[23] Cornely, O. A., Miller, M. A., Fantin, B., et al.: Resolution of Clostridium difficile-associated diarrhea in patients with cancer treated with fidaxomicin or vancomycin. J. Clin. Oncol., 2013, 31(19), 2493-2499.

[24] Mullane, K.: Fidaxomicin in Clostridium difficile infection: latest evidence and clinical guidance. Ther. Adv. Chronic Dis., 2014, $5(2), 69-84$.

[25] Mullane, K. M., Miller, M. A., Weiss, K., et al.: Efficacy of fidaxomicin versus vancomycin as therapy for Clostridium difficile infection in individuals taking concomitant antibiotics for other concurrent infections. Clin. Infect. Dis., 2011, 53(5), 440-447.

[26] Mullane, K. G., Crook, D., Cornely, O. A., et al.: Renal impairment and response to fidaxomicin versus vancomycin in patients with Clostridium difficile infection. Proc. 49th Annual Meeting Infectious Diseases Society of America, October 20-23, 2011, Boston, MA.

[27] Cornely, O. A., Fantin, B., Mullane, K., et al.: Clostridium difficile-associated diarrhea in cancer patients treated with fidaxomicin or vancomycin. Annual Meeting of the American Society of Clinical Oncology, June 1-5, 2012, Chicago, IL.

[28] Lovie, T. J., Miller, M. A., Crook, D. W., et al.: Effect of age on treatment outcomes in Clostridium difficile infection. J. Am. Geriatr. Soc., 2013, 61(2), 222-230.

[29] Pépin, J., Routhier, S., Gagnon, S., et al.: Management and outcomes of a first recurrence of Clostridium difficile-associated disease in Quebec, Canada. Clin. Infect. Dis., 2006, 42(6), 758 764.

[30] Bakken, J. S.: Fecal bacteriotherapy for recurrent Clostridium difficile infection. Anaerobe, 2009, 15(6), 285-289.
[31] Benson, A. B. 3rd, Ajani, J. A., Catalano, R. B., et al.: Recom mended guidelines for the treatment of cancer treatment-induced diarrhea. J. Clin. Oncol., 2004, 22(14), 2918-2926.

[32] Gorschlüter, M., Hahn, C., Ziske, C., et al.: Low frequency of enteric infections by Salmonella, Shigella, Yersinia and Campylobacter in patients with acute leukemia. Infection, 2002, 30(1), 2225.

[33] McDonald, L. C., Killgore, G. E., Thompson, A., et al.: An epidemic, toxin gene-variant strain of Clostridium difficile. N. Engl. J. Med., 2005, 353(23), 2433-2441.

[34] Muldoon, E. G., Epstein, R., Logvinenko, T., et al.: The impact of cefepime as first line therapy for neutropenic fever on Clostridium difficile rates among hematology and oncology patients. Anaerobe, 2013, 24, 79-81.

[35] Cudmore, M. A., Silva, J. Jr., Fekety, R., et al.: Clostridium diffcile colitis associated with cancer chemotherapy. Arch. Intern. Med., 1982, 142(2), 333-335.

[36] Bishop, K. D., Castillo, J. J.: Risk factors associated with Clostridium difficile infection in adult oncology patients with a history of recent hospitalization for febrile neutropenia. Leuk. Lymphoma, 2012, 53(8), 1617-1619.

[37] Redelings, M. D., Sorvillo, F., Mascola, L.: Increase in Clostridium difficile-related mortality rates, United States, 1999-2004. Emerg. Infect. Dis., 2007, 13(9), 1417-1419.

[38] Stringer, A. M., Gibson, R. J., Bowen, J. M., et al.: Chemotherapyinduced modifications to gastrointestinal microflora: Evidence and implications of change. Curr. Drug Metab., 2009, 10(1), 79-83.

[39] Morales Chamorro, R., Serrano Blanch, R., Mendez Vidal, M. J., et al.: Pseudomembranous colitis associated with chemotherapy with 5-fluorouracil. Clin. Transl. Oncol., 2005, 7(6), 258-261.

[40] Resnik, E., Lefevre, C. A.: Fulminant Clostridium difficile colitis associated with paclitaxel and carboplatin chemotherapy. Int. J. Gynecol. Cancer, 1999, 9(6), 512-514.

[41] Emoto, M., Kawarabayashi, T., Hachisuga, M. D., et al.: Clostridium difficile colitis associated with cisplatin-based chemotherapy in ovarian cancer patients. Gynecol. Oncol., 1996, 61(3), 369372.

[42] Toi, Y., Sugawara, S., Kobayashi, T., et al.: Prospective study of chemotherapy-induced Clostridium difficile infection in lung cancer patients. J. Clin. Oncol., 2012, 30(15 Suppl.), e19521.

[43] Anand, A, Glatt, A. E.: Clostridium difficile infection associated with antineoplastic chemotherapy: a review. Clin. Infect. Dis., $1993,17(1), 109-113$

[44] El-Maballawy, H. A., El-Din, N. H., Attia, I. A., et al.: Clostridium difficile associated diarrhea in pediatric oncology patients receiving chemotherapy. J. Egypt. Nat. Cancer Inst., 2001, 13(4), 285-290.

[45] Ansari, J., Choo, B., Fernando, I.: Fatal Clostridium difficile infection associated with vinorelbine chemotherapy: case report and literature review. J. Infect. Chemother., 2010, 16(3), 210-212.

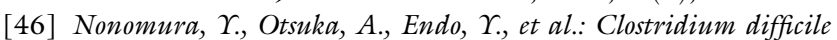
colitis and neutropenic fever associated with docetaxel chemotherapy in a patient with advanced extramammary Paget's disease. Case Rep. Dermatol., 2012, 4(2), 177-180.

[47] Khan, A., Raza, S., Batul, S. A., et al.: The evolution of Clostridium difficile infection in cancer patients: epidemiology, pathophysiology, and guidelines for prevention and management. Recent Pat. Antiinfect. Drug Discov., 2012, 7(2), 157-170.

[48] Fang, W. J., Jing, D. Z., Luo, Y., et al.: Clostridium difficile carriage in hospitalized cancer patients: a prospective investigation in eastern China. BMC Infect. Dis., 2014, 14, 523.

[49] Hwang, K. E., Hwang, Y. R., Seol, C. H., et al.: Clostridium difficile infection in lung cancer patients. Jpn J. Infect. Dis., 2013, $66(5), 379-382$.

[50] Gorschlüter, M., Glasmacher, A., Hahn, C., et al.: Clostridium difficile infection in patients with neutropenia. Clin. Infect. Dis., 2001, 33(6), 786-791. 
[51] Zacharioudakis, I. M., Ziakas, P. D., Mylonakis, E.: Clostridium difficile infection in the Hematopoietic Unit: A meta-analysis of published studies. Biol. Blood Marrow Transplant., 2014, 20(10), 1650-1654.

[52] Caimi, P. F.: Clostridium difficile infection is a frequent but wellcontrolled event after hematopoietic cell transplantation. Rev. Bras. Hematol. Hemoter., 2015, 37(6), 371-372.

[53] Stewart, D. B., Yacoub, E., Zhu, J.: Chemotherapy patients with C. difficile colitis have outcomes similar to immunocompetent $C$. difficile patients. J. Gastrointest. Surg., 2012, 16(8), 1566-1572.

[54] Heard, S. R., Wren, B., Barnett, M. J., et al.: Clostridium difficile infection in patients with haematological malignant disease. Risk factors, faecal toxins and pathogenic strains. Epidemiol. Infect., 1988, 100(1), 63-72.

[55] Bartlett, J. G.: Historical perspectives on studies of Clostridium difficile and difficile infection. Clin. Infect. Dis., 2008, 46(Suppl. 1), S4-S11.

[56] Loo, V. G., Bourgault, A. M., Poirier, L., et al.: Host and pathogen factors for Clostridium difficile infection and colonization. N. Engl. J. Med., 2011, 365(18), 1693-1703.

[57] Keller, J. M., Surawicz, C. M.: Clostridium difficile infection in the elderly. Clin. Geriatr. Med., 2014, 30(1), 79-93.

[58] Stevens, V., Dumyati, G., Fine, L. S., et al.: Cumulative antibiotic exposures over time and the risk of Clostridium difficile infection. Clin. Infect. Dis., 2011, 53(1), 42-48.

[59] Hensgens, M. P., Goorhuis, A., Dekkers, O. M., et al.: Time interval of increased risk for Clostridium difficile infections after exposure to antibiotics. J. Antimicrob. Chemother., 2012, 67(3), 742748
[60] Kelly, C. P.: Can we identify patients at high risk of recurrent Clostridium difficile infection? Clin. Microbiol. Infect., 2012, 18(Suppl. 6), 21-27.

[61] D'Agostino, R. B. Sr., Collins, S. H., Pencina, K. M., et al.: Risk estimation for recurrent Clostridium difficile infection based on clinical factors. Clin. Infect. Dis., 2014, 58(10), 1386-1393.

[62] Lonie, T. J., Miller, M. A., Mullane, K. M., et al.: Fidaxomicin versus vancomycin for Clostridium difficile infection. N. Engl. J. Med., 2011, 364(5), 422-431.

[63] Esmaily-Fard, A., Tverdek, F. P., Crowther, D. M., et al.: The use of fidaxomicin for treatment of relapsed Clostridium difficile infections in patients with cancer. Pharmacotherapy, 2014, 34(11), $1220-1225$.

[64] Yoon, Y. K., Kim, M. J., Sohn, J. W., et al.: Predictors of mortality attributable to Clostridium difficile infection in patients with underlying malignancy. Support. Care Cancer, 2014, 22(8), 20392048 .

[65] Rodriguez Garzotto, A., Mérida García, A., Muñoz Unceta, N., et al.: Risk factors associated with Clostridium difficile infection in adult oncology patients. Support. Care Cancer, 2015, 23(6), $1569-1577$.

[66] Krishna, S. G., Zhao, W., Apewokin, S. K., et al.: Risk factors, preemptive therapy, and antiperistaltic agents for Clostridium difficile infection in cancer patients. Transplant Infect. Dis., $2013,15(5), 493-501$

(Telekes András dr., Budapest, Maglódi út 89-91., 1106 e-mail: andras.telekes@bajcsy.hu)

\section{FELHÍVÁS \\ folyóirat-referátumok beküldésére}

A Semmelweis Egyetem Továbbképző Központjának döntése értelmében

2016. január 1-jétöl folyamatosan orvos-továbbképzési pontokat kaphatnak a nemzetközi, impaktfaktoros folyóiratokban megjelent közlemények rövid összefoglalásának, referátumának beküldői.

Az Orvosi Hetilap hasábjain megjelenő és közlésre elfogadott referátum után 1 pont, félévente maximum 12 továbbképzési pont gyưjithető, amelyet félévente összesitve továbbitunk a továbbképzési központok felé.

Távoktatással szerzett pontokból évente legfeljebb 20 pont számítható be.

Aki továbbképzési pontot kiván gyüjteni, a referátum beküldésekor adja meg pecsétszámát.

Várjuk lelkes, továbbképzési pontokat gyüjteni kivánó referálóink jelentkezését!

\section{A referátum fejlécében az alábbi adatokat kérjük megadni:}

A cikk címe magyarul, zárójelben az angol cím

A szerző(k) neve (vezetéknév, a keresztnevet jelölő betü(k) - 3 szerzőig, háromnál több szerző esetén et al.), a levelező szerző neve, munkahelye és e-mail címe)

A folyóirat neve - a szokásos nemzetközi rövidítés szerint (PubMed), évszám, kötetszám, füzetszám, a cikk kezdő és utolsó oldalszáma

A referátumot elektronikus úton (Editorial Manager vagy e-mail: edit.budai@akademiai.hu) kérjük elküldeni. 